\title{
BUSINESS STRATEGY FOR PROPERTY DEVELOPMENT IN CENGKARENG BUSINESS CITY AREA
}

\author{
Henri Suharlim \\ Program Studi Magister Manajemen Universitas Tarumanagara \\ joanfelix_heinreich@yahoo.com \\ Rina Adi Kristianti \\ Program Studi Magister Manajemen Universitas Tarumanagara
}

\begin{abstract}
The massive growth of real estate development in Jakarta especially in near area Soekarno-Hatta International Airport and rapid growth Indonesia economic condition due to tax amnesty program that held by government, should increase opportunity for the local and international real estate developer company. This business plan will provide the information and basic concept that needed by business strategist or investors in evaluating aspect feasibility and as guidelines and strategic information for next managers who try to develop suitable construction business concept in Cengkareng, Jakarta Barat which is the location itself near with international airport .This business concept aim to become basic concept for the marketers and business strategist in Cengkareng Business City (CBC) to redevelope blank site area into suitable and profitable building product for the investors by providing useful information, calculation, and design concept for next project in CBC . Based on result of businessn plan feasibility study, this business plan is calculated to achieve good results for investment by gaining NPV value of Rp219,556,798,184.16, by using assumption cost of capital $10 \%$. It also planned to gain IRR value $30 \%$, it bigger than yearly rate $10 \%$. It shows that the investment for this business plan can exceed the rate of investment that aimed by $\mathrm{CBC}$ investors themselves .
\end{abstract}

Keywords : business plan, construction, design buildings and concept, aerotropolis , feasibility study

Abstrak : Pertumbuhan bisnis real estate di Jakarta yang pesat khususnya di daerah sekitar Bandara Udara Soekarno - Hatta dan kondisi pertumbuhan ekonomi di Indonesia yang cepat akibat program tax amnesty yang dijalankan oleh pemerintah, kondisi tersebut seharusnya dapat meningkatkan peluang bagi pengembang properti baik dari dalam negeri maupun luar negeri . Business Plan ini memberikan informasi dan konsep dasar yang dibutuhkan oleh strategis bisnis atau investor dalam mengevaluasi faktor kelayakan dan sebagai pedoman informasi strategis bagi manajer berikutnya yang mencoba untuk mengembangkan konsep bisnis yang tepat untuk kawsan dekat bandara udara di Cengkareng, Jakarta Barat . Konsep bisnis ini bertujuan untuk menjadi konsep dasar bagi para pelaku pasar dan para strategis bisnis di Cengkareng Business City (CBC) untuk mengembangkan tanah kosong yang ada menjadi produk bangunan yang cocok dan menguntungkan bagi para investor dengan memberikan informasi yang tepat, kalkulasi, dan konsep desain untuk proyek berikutnya . Berdasarkan hasil studi kelayakan, rencana bisnis ini diperhitungkan untuk mencapai hasil yang menguntungkan bagi investasi dengan memperoleh nilai NPV sebesar Rp219,556,798,184.16 , dengan asumsi cost of capital 10\% . Konsep ini direncanakan untuk memperoleh nilai IRR $30 \%$, dimana lebih besar dari rate tahunan sebesar $10 \%$. Hal ini menunjukkan bahwa investai untuk rencana bisnis ini dapat melebihi acuan investasi yang telah ditetapkan oleh para investor .

Keyword : business plan, konstruksi, konsep desain , aerotropolis , studi kelayakan 


\section{PENDAHULUAN}

Kawasan di sekeliling Bandara Soekarno-Hatta, Tangerang, Banten, kini menjadi salah satu sentra baru pengembangan properti di Jabodetabek. Selain meladeni kebutuhan hunian karyawan yang bekerja di bandara yang terus meningkat seiring dengan makin banyaknya maskapai penerbangan yang singgah di terminal pesawat terbesar di. Melihat tren perkembangan properti saat ini yang mulai mengarah ke daerah sekitar bandara . Pusat kota kini tidak lagi menjadi satu-satunya kawasan yang diincar untuk perluasan bisnis para pengembang.

Permasalahan yang ada dan sedang dialami oleh perusahaan CBC adalah kurang matangnya konsep bisnis yang akan diterapkan. Dengan lahan seluas $38 \mathrm{Ha}$ dengan akses yang sangat dekat dengan Bandara Soekarno Hatta, perusahaan ini kesulitan melahirkan inovasi product dan gagasan konsep kawasan CBC. Hal ini dapat terlihat dari sulitnya mengambil keputusan yang terlihat dari perkembangan masterplan di bawah ini dimana master plan CBC terus berubah - rubah dan hingga akhirnya terdapat area LOT yang dikosongkan .

Tidak matangnya konsep bisnis dan master plan untuk kawasan $\mathrm{CBC}$, menyebabkan beberapa persoalan :

- Bongkar-pasang infrastruktur yang sudah berjalan ataupun sudah jadi di lapangan . Hal ini merupakan pemborosan dari segi biaya dan waktu

- Sering terjadi bongkar - pasang instalasi mechanical - electrical - plumbing karena ketidak pastian master plan

\section{BAHAN DAN METODE PENELITIAN}

Metode peneletian yang dipakai untuk penelitian ini memakai metode dengan pendekatan deskripsi secara sistematis, faktual, dan akurat mengenai fakta dan sifat populasi atau daerah tertentu dan mempelajari secara intensif latar belakang keadaan sekarang (deskriptif ) dan interaksi lingkungansuatu obyek ( studi kasus ). Dengan mempelajari kondisi proyek eksisting termasuk interaksi proyek terhadap lingkungan, infrastruktur yang ada , kondisi sosial , maupun karakteristik pembeli di kawasan ini . Data - data yang diperoleh penulis sebagai dasar penelitian ini adalah pengamatan langsung di lapangan ,studi literatur yang berhubungan dengan penelitian ini. Area yang diteliti adalah area lot 8 dan lot 9 karena area tersebut memiliki lokasi yang sangat strategis dibandingkan area lain . Area tersebut berada di tengah kawasan dan memiliki akses langsung ke jalan primer kawasan .

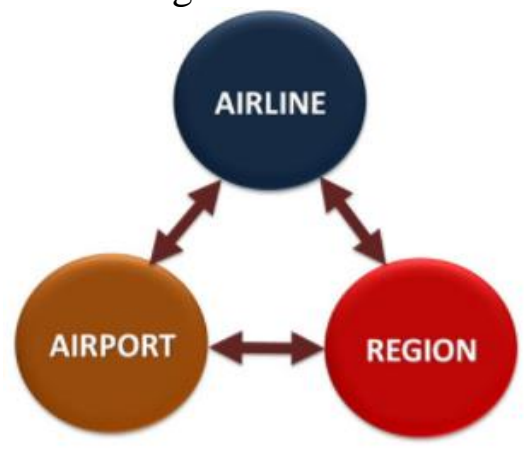

\section{HASIL PENELITIAN}

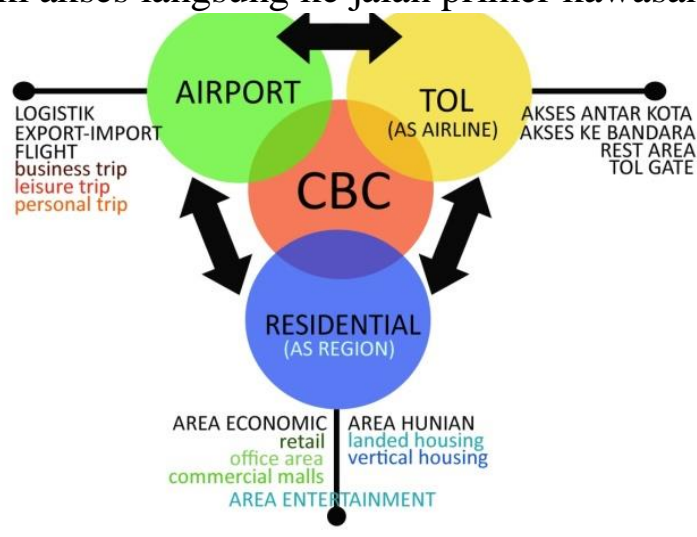

Menurut penulis, untuk pengisian LOT 8 dan LOT 9 untuk next project, dapat dikembangkan dengan memilih konsep rental apartemen LOFTS + retail area + terminal shuttle bus . Alasan dipilih konsep tersebut adalah : 
- ada kompetitor lain yakni intiland yang mengembangkan konsep apartemen sewa yakni aeropolis dan terbukti sold out

- sudah jelas ada peminatnya, yakni para pekerja kawasan bandara dan perusahaan maskapai penerbangan

- investasi yang dikeluarkan untuk membangun lebih murah

- CBC sudah memiliki pengalaman di bidang apartemen dan retail, dan sudah menunjuk operator traffic kawasan CBC yakni Secure Parking

\section{PEMBAHASAN}

Karena sudah diketahui biaya struktur memiliki nilai tertinggi, maka untuk menekan biaya konstruksi awal dan memudahkan marketing untuk menentukan nilai sewa dan biaya operasional dan maintenance ke depannya maka :

- Apartemen dibuat model loft, karena dengan model loft dapat menghemat pekerjaan struktur sebesar $30-40 \%$

- Apartemen dibuat tanpa basement untuk menghindari biaya structural basement dan galian tanah, komposisi pekerjaan basement memiliki komposisi sebesar 50\% dari nilai pekerjaan struktur keseluruhan gedung .

- Untuk terminal dan komersial dibuat dengan konsep terbuka, dengan tujuan meminimalisir pemakaian material arsitektur, dan memberi kebebasan bagi para penyewa untuk mengolah ruang sewa di kawasan komersial .

ASUMSI PERHITUNGAN

PENDAPATAN

\begin{tabular}{|c|c|c|c|}
\hline & Jumlah Kamar & 96 & unit \\
\hline & Harga/Kamar & per bulan & per tahun \\
\hline & $4,000,000$ & 12 & $\mathrm{Rp} 48,000,000.00$ \\
\hline & luas unit & 63 & \\
\hline & Occupancy Rate (100\%) & 96 & Rp4,608,000,000.00 \\
\hline & $\begin{array}{r}\text { Room Income / tahun } \\
\text { IPL Income / tahun } \\
\text { (Rp15.000, - x luas unit) }\end{array}$ & $\begin{array}{l}12 \text { bulan } \\
12 \text { bulan }\end{array}$ & $\begin{array}{l}\text { Rp4,608,000,000.00 } \\
\text { Rp1,080,000,000.00 }\end{array}$ \\
\hline apartemen & & total & Rp5,688,000,000.00 \\
\hline & $\begin{array}{l}\text { income parkir langganan } \\
\text { kapasitas } 250 \text { unit mobil (asumsi } 50 \% \\
\text { terisi) } \\
\text { biaya perbulan } \\
\text { (asumsi penghuni memakai parkir } \\
\text { langganan) }\end{array}$ & $\begin{array}{l}12 \text { bulan } \\
150,000\end{array}$ & Rp450,000,000.00 \\
\hline parkir & $\begin{array}{l}\text { income parkir biasa } \\
25 \text { bus } \\
210 \text { unit mobil (asumsi 50\% terisi) }\end{array}$ & $\begin{array}{r}2400000 \\
570000\end{array}$ & $\begin{array}{r}\text { Rp720,000,000.00 } \\
\text { Rp1,436,400,000.00 }\end{array}$ \\
\hline
\end{tabular}




\begin{tabular}{|c|c|c|c|}
\hline & biaya perbulan & & \\
\hline & & total & Rp2,606,400,000.00 \\
\hline \multirow[b]{2}{*}{ komersial } & $\begin{array}{l}\text { comercials income / tahun } \\
\text { biaya sewa Rp } 300.000,- \text { / bulan / sqm } \\
\text { luas total area komersial : }\end{array}$ & $\begin{array}{l}12 \text { bulan } \\
12140\end{array}$ & Rp50,988,000,000.00 \\
\hline & $\begin{array}{l}\text { service charge komersial area / bln } \\
\text { Rp.75.000,- }\end{array}$ & 12 bulan & Rp10,926,000,000.00 \\
\hline & & $\begin{array}{l}\text { Total } \\
\text { Income }\end{array}$ & Rp70,208,400,000.00 \\
\hline & \multicolumn{2}{|c|}{ Gross Operational Profit (40\% x Total Income) } & Rp28,083,360,000.00 \\
\hline & \multicolumn{2}{|c|}{ Break Even Year (Investasi Bangunan) } & $\mathbf{7 . 5 4 3 3 7 8 0 7 9}$ \\
\hline & \multicolumn{2}{|c|}{ Break Even Year (Bangunan + Tanah) } & Rp11.69 \\
\hline
\end{tabular}

note rata - rata biaya sewa apartemen aeropolis perbulan = Rp. 2.200.000,-

Jika melihat perhitungan di atas, dengan penetapan harga :

- harga sewa unit apartemen per bulan Rp. 4.000.000,- disertai biaya IPL per meter persegi Rp 15.000,-

- biaya parkir langganan per bulan Rp 150.000,- dan ongkos parkir per jamnya mengikuti harga standar

- harga sewa area komersial perbulan Rp 300.000,- per meter persegi disertai biaya maintenance IPL Rp 75.000,-

Maka investasi bangunan dan konstruksi akan balik modal ke investor / break event point di tahun ke 7 setelah bangunan beroperasional dengan asumsi occupancy rate untuk unit apartemen mencapai $75 \%$ dan gross profit $40 \%$ dan asumsi kapasitas parkir terisi $50 \%$.

Perhitungan NPV berdasarkan asumsi di atas

\begin{tabular}{|c|c|c|c|c|}
\hline $\begin{array}{c}\text { Tahun } \\
\text { ke }\end{array}$ & $\begin{array}{c}\text { Cash Income Setelah } \\
\text { Pajak }\end{array}$ & DF & $10 \%$ & Present Value Cash Income \\
\hline 0 & -Rp211,843,427,000.00 & & 1.00 & -Rp211,843,427,000.00 \\
\hline 1 & Rp70,208,400,000.00 & & 0.91 & Rp63,825,818,181.82 \\
\hline 2 & Rp70,208,400,000.00 & & 0.83 & Rp58,023,471,074.38 \\
\hline 3 & Rp70,208,400,000.00 & & 0.75 & Rp52,748,610,067.62 \\
\hline 4 & Rp70,208,400,000.00 & & 0.68 & Rp47,953,281,879.65 \\
\hline 5 & Rp70,208,400,000.00 & & 0.62 & Rp43,593,892,617.87 \\
\hline 6 & Rp70,208,400,000.00 & & 0.56 & Rp39,630,811,470.79 \\
\hline 7 & Rp70,208,400,000.00 & & 0.51 & Rp36,028,010,427.99 \\
\hline 8 & Rp70,208,400,000.00 & & 0.47 & Rp32,752,736,752.72 \\
\hline 9 & Rp70,208,400,000.00 & & 0.42 & Rp29,775,215,229.74 \\
\hline 10 & Rp70,208,400,000.00 & & 0.39 & Rp27,068,377,481.58 \\
\hline \multicolumn{4}{|c|}{ TOTAL NPV } & Rp219,556,798,184.16 \\
\hline & & & & Rp219,556,798,184.16 \\
\hline
\end{tabular}


Dengan usulan investasi awal untuk proyek CBC di lot 8 dan lot 9 sebesar Rp211,843,427,000.00 . tanpa nilai sisa , dan menghasilkan cash income per tahunnya sebesar Rp70,208,400,000.00 selama 7 tahun .

\section{KESIMPULAN}

Setelah sempat melemahnya kondisi pasar properti di Indonesia , kini memasuki tahun 2018 , kondisi tersebut belum juga menunjukkan pemulihan yang signifikan. Namun ditengah lesunya pasar properti saat ini tidak menutup kemungkinan adanya kesempatan yang dapat dimanfaatkan untuk memperoleh keuntungan .

Dengan berbagai pertimbangan yang sudah disebutkan di atas, maka rencana lahan kosong di LOT 8 dan LOT 9 direncanakan pembangunan mixed use area dengan gabungan antara lofts apartemen - shuttle terminal - commercial zone tanpa adanya basement . Produk yang penulis ajukan untuk di launching terdiri dari :

\section{DATA RENCANA PRODUCT YANG AKAN}

\section{LAUNCHING}

\begin{tabular}{|c|c|c|c|c|}
\hline \multicolumn{5}{|c|}{ LOFTS APARTEMEN } \\
\hline NO & ITEM & $\begin{array}{c}\text { QTY } \\
\text { (UNIT) }\end{array}$ & $\begin{array}{l}\text { LUAS } \\
\text { PER } \\
\text { UNIT }\end{array}$ & LUAS TOTAL \\
\hline 1 & $\begin{array}{l}\text { APARTEMEN UNIT } \\
\text { PARKIR }\end{array}$ & $\begin{array}{c}96 \\
500\end{array}$ & 62.5 & 6000 \\
\hline 2 & APARTEMEN & cars & 12.5 & 6250 \\
\hline 3 & KOMERSIAL UNIT & 12 & 120 & 1440 \\
\hline \multicolumn{5}{|c|}{ SHUTTLE BUS TERMINAL } \\
\hline 1 & $\begin{array}{l}\text { TERMINAL + } \\
\text { LOUNGE }(\text { LEFT) } \\
\text { TERMINAL + }\end{array}$ & 1 & 675 & 675 \\
\hline 2 & LOUNGE (RIGHT) & 1 & 4550 & 4550 \\
\hline \multicolumn{5}{|c|}{ COMMERCIALS ZONE } \\
\hline $\begin{array}{l}1 \\
2\end{array}$ & $\begin{array}{l}\text { KOMERSIAL AREA } \\
\text { AREA PARKIR + } \\
\text { SIRKULASI }\end{array}$ & $\begin{array}{c}20 \\
420 \\
\text { cars } \\
25 \\
\text { buses }\end{array}$ & - & $\begin{array}{l}5350 \\
5300\end{array}$ \\
\hline
\end{tabular}

\section{DAFTAR PUSTAKA}

- Adi Kristianti , Rina. (2017) .Manajemen Strategik .Tangerang :Pustaka Mandiri.

- Ernest and Neufert, Peter. (2002). Architect Data (3rd edition). Oxford: The Alden Group.

- Harian, Cara . (2017) .Rumus NPV di Excel .Diperoleh 10 juli2017 .dari http://caraharian.com/rumus-npv.html

- Porter, Michael E danMaulana,Agus .(1996). StrategiBersaing .Jakarta : Erlangga. 
